\title{
Surface characteristics and bioactivity of minocycline-treated Ti-6Al-4V alloy
}

\author{
Jung-Hyuk Lee ${ }^{\dagger}$, Young-Gon Sun ${ }^{\dagger}$, Eui-Ri Na, Jong-Wook Moon, Young-Joon Kim*
}

Department of Periodontology, School of Dentistry, Chonnam National University, Gwangju, Korea

\begin{abstract}
Chemical agents such as minocycline (MC) and citric acid (CA) were suggested in the treatment of contaminated implant surface. In this study, $\mathrm{MC}-\mathrm{HCl}$ treatment was performed to enhance surface characteristics of titanium alloy surface. The purpose of this study was to assess the characteristics and the biocompatibility of Ti-6Al-4V surface treated by MC. Alpha-beta titanium alloy (Ti-6Al-4V) samples were prepared and they were divided into 6 groups according to chemical concentration and treatment time. These groups include 1) group I, non-treated smooth titanium alloy; 2) group II, MC $1.5 \mathrm{mg} / \mathrm{mL}$ for 1 hour; 3) group III, MC $1.5 \mathrm{mg} / \mathrm{mL}$ for 24 hours; 4) group IV, MC $15 \mathrm{mg} / \mathrm{mL}$ for 10 minutes; 5) group V, MC $100 \mathrm{mg} / \mathrm{mL}$ for 5 minutes; 6) group VI, pH1 CA for 3 minutes. The analysis of the surface characteristics of MC-treated titanium alloy was executed using scanning electron microscopy, roughness test, and X-ray photoelectron spectroscopy (XPS). Cell adhesion and MTT assay was done using MC3T3 cell. Titanium surfaces treated with $\mathrm{MC}$ indicated a more smoothened surface microstructure. For group II and III, the new peaks of rutile $\mathrm{TiO} 2$ were found. Group II and V have more basic group of Ti-OH form in XPS. In MTT assay, all MC-treated groups showed significantly higher cell viability compared to control. The surface roughness, crystal structure, surface hydrophilicity, cell viability of smooth titanium surface was improved by MC treatment. Compared with the control experiment and CA-treated group, smooth titanium surface treated with MC showed improved surface characteristics and cell biocompatibility.
\end{abstract}

Key Words: Biocompatibility, MC3T3 cell, Minocycline, Surface modification

@) This is an open-access article distributed under the terms of the Creative Commons Attribution Non-Commercial License (http://creativecommons.org/licenses/by-nc/4.0) which permits unrestricted noncommercial use, distribution, and reproduction in any medium, provided the original work is properly cited.

\section{INTRODUCTION}

Titanium has been preferred in materials of dental implants due to its mechanical strength and favorable biocompatibility [1]. Ti alloys were developed to improve mechanical properties and corrosion resistance of commercially pure titanium. It has been reported that $\mathrm{Ti}^{-}$ $6 \mathrm{Al}-4 \mathrm{~V}$ alloy has higher mechanical strength than that of pure Ti [2]. As a result, Ti-6Al-4V alloy has been frequently used for fabricating dental implant abutment [3].

In spite of the excellent biological properties of titanium for implant material, complications like peri-implant disease may cause the failure of the titanium dental implants [4]. Confronting the onset of peri-implantitis, decontamination of implant surface is crucial assignment to resolve peri-implant inflammation and obtain reosseointegration [5]. For debridement of contaminated surfaces, chemical agents include citric acid (CA),

Received June 21, 2018; Revised September 6, 2018; Accepted October 4, 2018

Corresponding author: Young-Joon Kim, Department of Periodontology, School of Dentistry, Chonnam National University, 33 Yongbong-ro, Buk-gu, Gwangju 61186, Korea.

Tel: +82-62-530-5648, Fax: +82-62-530-5649, E-mail: youngjun@chonnam.ac.kr

${ }^{\dagger}$ These authors contributed equally to this work.

Copyright $\odot$ 2018, Oral Biology Research Institute 
tetracycline, saline, chlorhexidine, hydrogen peroxide and doxycycline were commonly employed [6].

The tetracyclines are antibiotics that act by inhibition of protein synthesis. Besides for their antibiotic properties, tetracyclines possess several unique characteristics like collagenase inhibition, inhibition of neutrophil chemotaxis, anti-inflammatory effects and root surface conditioning. Those characteristics could be account for their efficacy in periodontal treatment [7].

Data from clinical researches on the treatment of periimplantitis suggest different methods by using chemical agents. In the clinical study by Mellonig et al. [8], the titanium surface was detoxified with a solution of 50 $\mathrm{mg} / \mathrm{mL}$ tetracycline- $\mathrm{HCl}$, in contact with the titanium surface remaining for 2 to 3 minutes. Renvert et al. [9] observed that both probing pocket depth and bleeding on probing scores were reduced by using local delivery of minocycline (MC) microspheres. Zhou et al. [10] reported that local delivery of $\mathrm{MC}-\mathrm{HCl}$ (Periocline; Dongkook Co., Seoul, Korea) could be effectively used in treating periimplantitis in cases without peri-implant fistula. A method of local drug delivery can attain higher concentrations in subgingival sites which was 100-fold higher than that of a systemic drug delivery method. For example, local delivery of $\mathrm{MC}-\mathrm{HCl}$ can show drug concentrations in excess of $1500 \mu \mathrm{m} / \mathrm{mL}$ in gingival cervicular fluid after 24 hour of drug administration. MC concentrations in the periodontal pockets decreased gradually for 7 days after administration [11].

In the study reported by Mouhyi et al. [12], treatment of CA to titanium surface derived a result of cleaner titanium surface as observed by scanning electron microscopy (SEM) than the surface of untreated control [12]. Overall, the use of antibiotics like MC and chemical agents resulted in improvement of soft tissue inflammation around periimplant lesion.

Although the majority of studies on implant detoxification are focused on the removal of bacterial biofilms, there has been little emphasis placed on the changes in morphological surface properties that can occur when an implant surface is subjected to chemical detoxifacation. In addition to, there has been a lack of comprehensive understanding on the effectiveness of MC treatment to titanium surface.

In this study, MC treatment was performed to remove bacterial bioflms and to improve biocompatibility of titanium surface. The purpose of this study was to evaluate surface characteristics and the biocompatibility of MC treated smooth titanium alloy surface.

\section{MATERIALS AND METHODS}

\section{Titanium disks}

Titanium alloy (Ti-6Al-4V) samples were manufactured as disks in two different diameters $(15 \mathrm{~mm}$ diameter and 4 $\mathrm{mm}$ thickness, $4 \mathrm{~mm}$ diameter and $4 \mathrm{~mm}$ thickness) from Titanium Center (Gwangju, Korea). In this study, Ti-6Al$4 \mathrm{~V}$ alloy was used rather than pure titanium for assumption of clinical situation. Dental implant abutment, the most portion of contacting chemical agent, was generally made of Ti-6Al-4V [13]. Titanium alloy disks were wet ground by using progressively finer diamond paper (Deerfos Co., Incheon, Korea) up from 800 to 2,000 grit size. Disks were ultrasonically degreased in $99.8 \%$ acetone and followed by distilled water for 10 minutes respectively. The washing procedures were repeated three times.

\section{MC treatment}

Each sample was soaked with $\mathrm{MC}-\mathrm{HCl}$ (Dongkook Co.) solution in different conditions. Specimens were divided into 6 groups according to their concentration and treating time (Table 1). Group I was non-treated control group. Group II, III, IV, V, and VI were MC or CA-treated groups. The immersion time of each group was varied with the concentration, which set up conditions reference to clinical situations associated with implant surface treatment, such as $\mathrm{MC}-\mathrm{HCl}$ ointment local delivery or diluted irrigation of MC-HCl solution [8-10].

\section{SEM}

The surface morphology of MC-treated Ti-6Al-4V alloy disks was observed by SEM (S-4700; Hitachi, Tokyo, Japan). 
Table 1. Treatment condition of each group

\begin{tabular}{clc}
\hline Group & Chemical concentration & Immersion time \\
\hline Group I & $\begin{array}{l}\text { Non treated } \\
\text { Smooth titanium surface }\end{array}$ & - \\
Group II & MC $1.5 \mathrm{mg} / \mathrm{mL}$ & $1 \mathrm{~h}$ \\
Group III & MC $1.5 \mathrm{mg} / \mathrm{mL}$ & $24 \mathrm{~h}$ \\
Group IV & MC $15 \mathrm{mg} / \mathrm{mL}$ & $10 \mathrm{~min}$ \\
Group V & MC $100 \mathrm{mg} / \mathrm{mL}$ & $5 \mathrm{~min}$ \\
Group VI & Citric acid $(\mathrm{pH} 1)$ & $3 \mathrm{~min}$ \\
\hline
\end{tabular}

MC, minocycline.

\section{Roughness test}

Roughness test was performed using an electronic portable surface roughness tester (Diavite dh-7; ASMETO AG, Basel, Switzerland) for MC-treated titanium alloy surface. Triplicate specimens of all groups were included.

\section{X-ray diffractometer (XRD) test}

To analyze the variation of crystal form of each group, the XRD test was performed. The surface of the MCtreated Ti-6Al-4V alloy disks were analyzed with an XRD (DMAX/1200; Rigaku, Tokyo, Japan) using CuKa1 incident radiation, a tube voltage of $40 \mathrm{kV}$ and a current of $40 \mathrm{~mA}$. Scanning speed was $2^{\circ} / \mathrm{min}$ and the scanning angle was ranged from $20^{\circ}$ to $90^{\circ} 2 \theta$.

\section{X-ray photoelectron spectroscopy (XPS) test}

XPS test was executed to analyze the surface composition of oxide and $\mathrm{OH}$ groups. The surface composition was examined by XPS (Multilab 2000; Thermo Electron, Waltham, MA, USA).

\section{Contact angle test}

The contact angles were determined after dropping distilled water at room temperature. The images of the distilled water droplet were taken at 30 seconds after delivery. The contact angle of each sample was measured using an image analyzing microscope (Camscope, Sometech
Inc., Seoul, Korea) and using software (Surften.4.5; OEG, Berlin, Germany).

\section{Cell culture}

Mouse MC3T3-E1 cells (ATCC; Rockville, MD, USA) were an immortalized cell-line as pre-osteoblast. The cells were cultured in T-75 flasks in alpha minimum essential medium ( $\alpha$-MEM; Invitrogen, Carlsbad, CA, USA) supplemented with 10\% heat-inactivated fetal bovine serum (FBS; Invitron Co., St. Louis, MO, USA), $100 \mathrm{mg} / \mathrm{mL}$ penicillin, and $100 \mathrm{mg} /$ $\mathrm{mL}$ streptomycin (Invitrogen, Carlsbad, CA, USA) at $37^{\circ} \mathrm{C}$ in a humidified atmosphere of $5 \% \mathrm{CO}_{2}-95 \%$ air.

\section{Evaluation of cell attachment}

The titanium alloy disks $(15 \mathrm{~mm}$ diameter and $4 \mathrm{~mm}$ thickness) were placed, under aseptic conditions, in the bottom of 12-well culture dishes, and then rinsed three times in 70\% ethanol, exposed to ultraviolet light for 1418 hours, and air dried in the cell culture hood. Cells were seeded in a 12 -well plate at a density of $1 \times 10^{4}$ cells $/ \mathrm{mL}$ in $\alpha$-MEM medium containing 10\% FBS. After incubation for 1 day, the dishes were washed three times with phosphate buffered saline and fixed with $2.5 \%$ glutaraldehyde in 100 $\mathrm{mM}$ cacodylate buffer. The samples were dehydrated in increasing concentrations of ethanol $(30 \%, 60 \%, 95 \%$, and $100 \%$ ), immersed in hexamethyldisilazane (Sigma-Aldrich Co., St. Louis, MO, USA) for 15 minutes, air-dried, and immediately mounted on aluminum stubs and coated with carbon. Mouse MC3T3-E1 cells were evaluated for cell attachment and growth patterns by analyzing SEM images.

\section{Cell viability test}

MTT assay (CellTiter 96 Aqueous one; Promega, Madison, Wi, USA) was used to evaluate cell viability after incubation for 3 days. Titanium disks ( $4 \mathrm{~mm}$ diameter and $4 \mathrm{~mm}$ thickness) were placed in a 96-well plate. The cells $\left(1 \times 10^{4} /\right.$ $\mathrm{mL}$ ) were seeded and expected to attach on titanium disks for 3 days in alpha-MEM solution. The number of viable cells was estimated by the amount of Formazan reduction. Formazan accumulation was quantified by the absorbance 
at $490 \mathrm{~nm}$ using an spectrophotometeric microplate reader (VERSAmax; Molecular Device, Sunnyvale, CA, USA) and analyzed. The experiments were carried out in triplicate.

\section{Statistical analysis}

One-way analysis of variance and Tukey's post hoc test for repeated measurements were performed to examine the data for surface roughness, contact angle measurement, MTT assay with SPSS ver. 12.0 (SPSS Inc., Chicago, IL, USA). The results were considered to be significant at $p<0.05$.

\section{RESULTS}

\section{Surface and microstructural characteristics (SEM analysis)}

The surface morphology of each group was shown in Fig. 1. Non-treated control Ti-6Al-4V surface showed a uniform texture with straight coarse line. MC-treated specimens showed narrow gap between lines. CA-treated specimen showed more dense structure than MC-treated titanium.
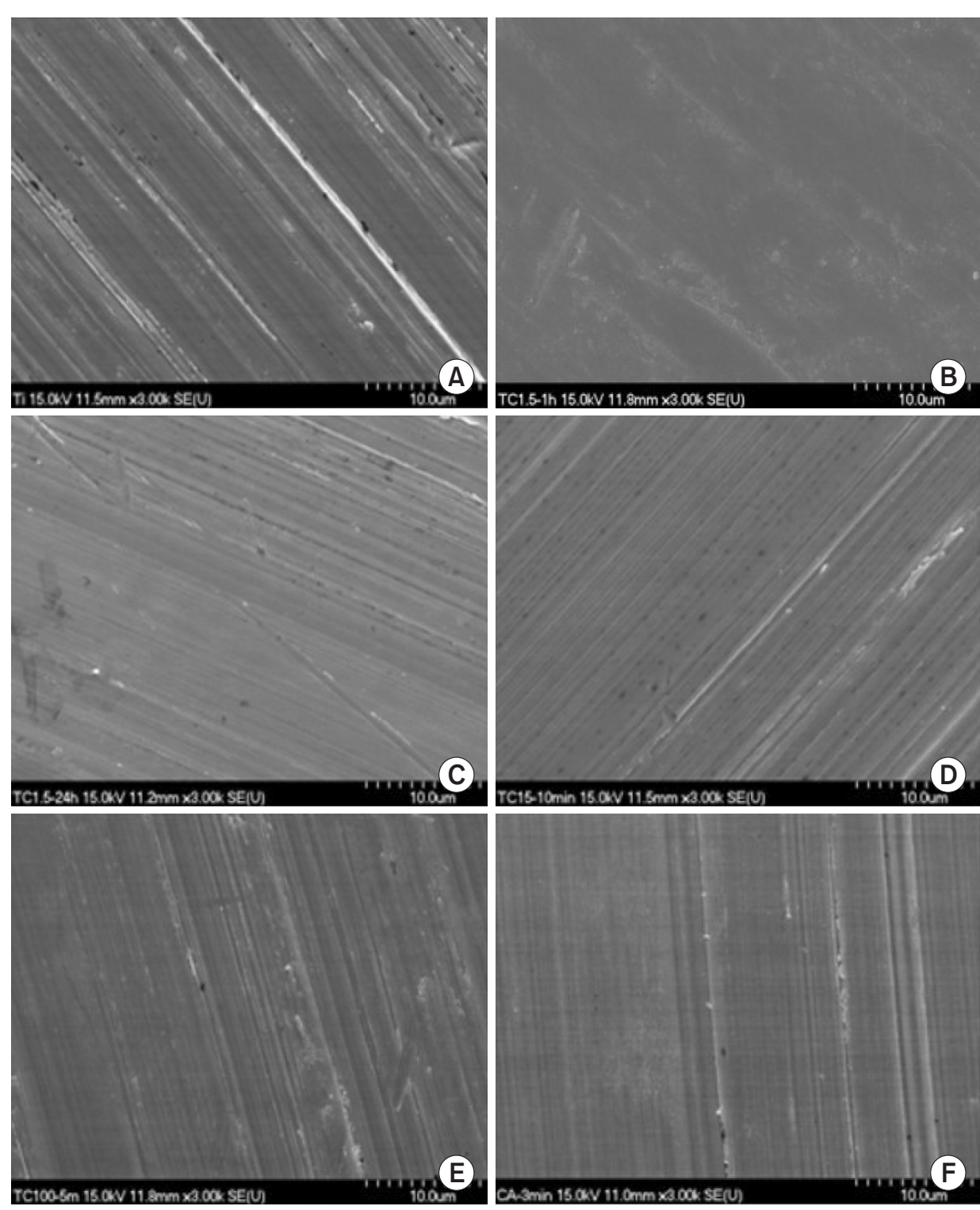

Fig. 1. The scanning electron microscopy images of titanium surface with or without minocycline (MC) treatment. (A) Group I: control, (B) group II: MC $1.5 \mathrm{mg} / \mathrm{mL} 1$ hour, (C) group III: MC $1.5 \mathrm{mg} / \mathrm{mL} 24$ hour, (D) group IV: MC $15 \mathrm{mg} / \mathrm{mL} 10$ minutes, (E) group V: MC $100 \mathrm{mg} / \mathrm{mL} 5$ minutes, (F) group VI: citric acid 3 minutes. 


\section{Roughness test}

The result of roughness test in each group was shown in Table 2. Roughness of group I, II, III, IV, V, and VI was $0.150,0.060,0.056,0.048,0.068$, and $0.053 \mu \mathrm{m}$, respectively. MC-treated groups and $\mathrm{CA}$-treated group have significantly lower roughness value compared to the control group $(p<0.05)$.

\section{XRD test}

Fig. 2 showed XRD patterns of samples. The pattern of the peaks demonstrated the portion of Ti- $6 \mathrm{Al}-4 \mathrm{~V}$ crystal form. The peaks were classified with their two- $\theta$ degrees. For all the specimens, similar pattern of the peaks was observed. Even though the most of peaks were composed of the alpha titanium peaks, group II and III showed the stronger intensity of the peaks belonging to rutile $\mathrm{TiO}_{2}(202)$ than the other groups. Furthermore, the intensity of the peaks belonging to anatase $\mathrm{TiO}_{2}(105,206)$ was increased in group II and III.

\section{XPS analysis}

Fig. 3 and Table 3 showed XPS survey on titanium surface treated with MC. The variation in portion of hydroxide groups was detected at each group. Generally, the portion of O1s Scan C was increased in $\mathrm{MC}$ - and $\mathrm{CA}^{-}$ treated groups. The portion of O1s Scan C which means the portion of Ti-OH belonging group II and $\mathrm{V}$ was higher

Table 2. Roughness value of each group $(n=3)$

\begin{tabular}{cc} 
Group & $\begin{array}{c}\text { The arithmetic average of the } \\
\text { roughness profile }(\mu \mathbf{m})\end{array}$ \\
\hline Group I & $0.150 \pm 0.009$ \\
Group II & $0.060 \pm 0.005^{\star}$ \\
Group III & $0.056 \pm 0.008^{\star}$ \\
Group IV & $0.048 \pm 0.003^{\star}$ \\
Group V & $0.068 \pm 0.004^{\star}$ \\
Group VI & $0.053 \pm 0.007^{\star}$
\end{tabular}

Values are presented as mean \pm standard deviation.

${ }^{\star}$ Significantaly different from the control group, $p<0.05$. than that of the other groups.

\section{Contact angle analysis}

Contact angle of each group was shown in Table 4. Group II, III, IV, and V have significantly lower contact angle than control group and group VI $(p<0.05)$.

\section{Cell attachment}

For each sample, the cell morphology and cell attachment were evaluated by SEM images (Fig. 4). All specimens have shown favorable cell adhesion and connection of dendritic process. Cell spreading was increased in MC-treated titanium alloy surfaces. In the group II and group III, more cell attachment was observed than the other groups and the number of cells with polygonal shape increased.

\section{MTT assay}

Cell viability was estimated by MTT assay (Table 5). On day 3, the MC-treated titanium surfaces were observed to have significantly increased cell proliferation compared with the control group and CA-treated group $(p<0.05)$.

\section{DISCUSSION}

Even though titanium has excellent biological properties, titanium implants may fail to osseointegrate commonly due to inflammation of peri-implant surface. Peri-implantitis was attributed to dental plaque formation. This oral biofilm was caused by oral bacterial colonization around the implant surface [14]. Removal of by-product from oral bacterial and reduction the level of micro-organisms is the crucial method in the treatment of peri-implant diseases [15]. Surface detoxification and debridement of contaminated implant surfaces can be effective way in removing bacterial biofilm, which may lead to reosseointegration [16]. Many of treatments used to detoxify titanium implants are either acidic or contain high concentrations of fluoride [17].

In this study, $\mathrm{MC}$ was treated to $\mathrm{Ti}-6 \mathrm{Al}-4 \mathrm{~V}$ alloy surface under different concentrations and immersion time to 

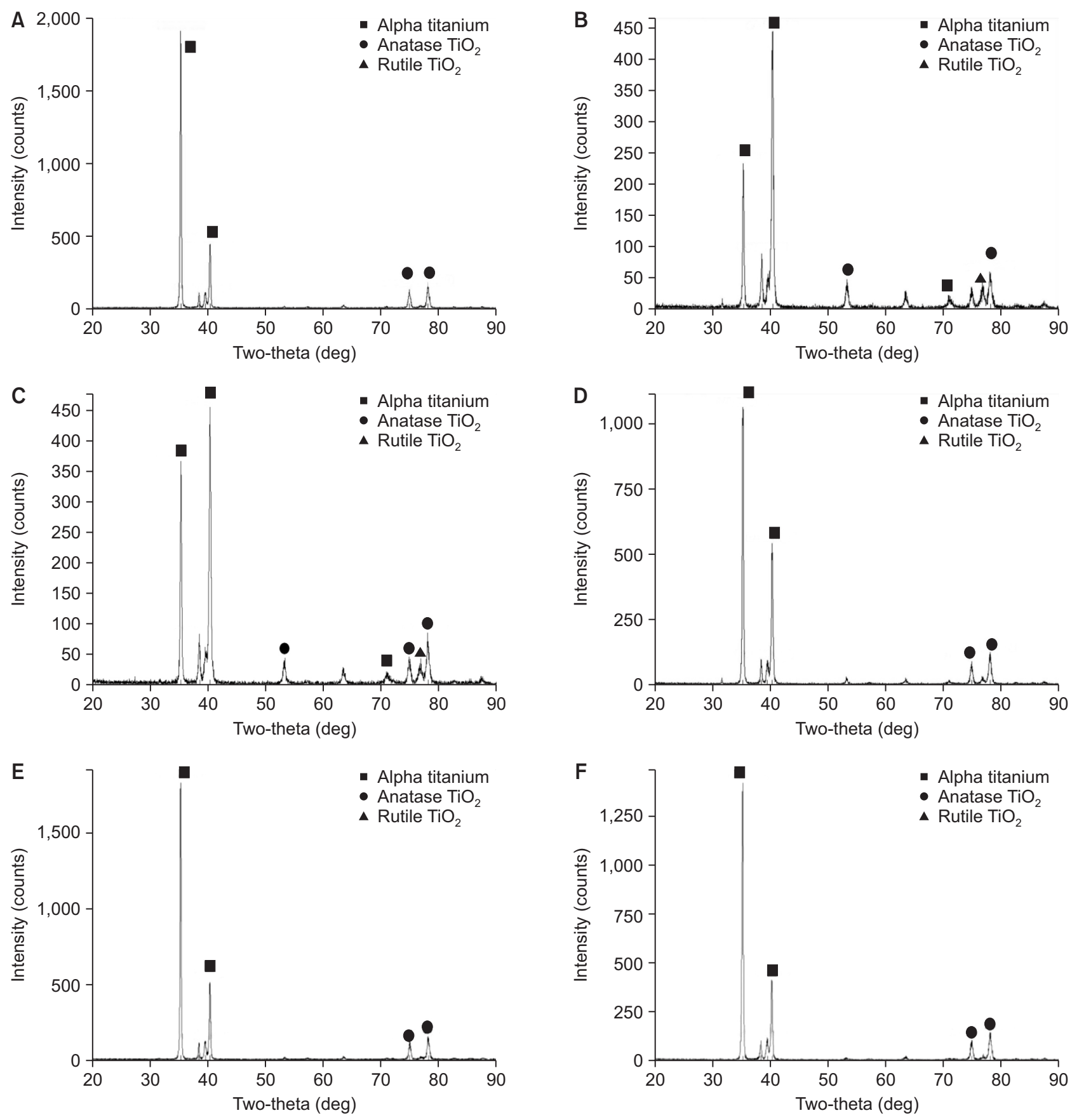

Fig. 2. X-ray diffractometer images of the specimens. (A) Group I: control, (B) group II: minocycline (MC) $1.5 \mathrm{mg} / \mathrm{mL} 1 \mathrm{hour}$, (C) group III: MC $1.5 \mathrm{mg} / \mathrm{mL} 24$ hour, (D) group IV: MC $15 \mathrm{mg} / \mathrm{mL} 10$ minutes, (E) group V: MC $100 \mathrm{mg} / \mathrm{mL} 5$ minutes, (F) group VI: citric acid $3 \mathrm{minutes.}$

improve biocompatibility and increase wettability. It was found that the change of surface roughness and increased wettability and favorable cell response with osteoblastic cell on titanium surfaces treated with MC.

The $\mathrm{MC}$ is antibiotic agent that acts by inhibition of protein synthesis. MC was one of the mostly frequently employed medications for treatment of the periodontal diseases. As a group, the tetracyclines were varied with their spectrum of antibacterial activity for gram-negative obligate anaerobes.

MC appears to be more effective in inhibition of gramnegative facultative anaerobes than tetracycline [18]. From 

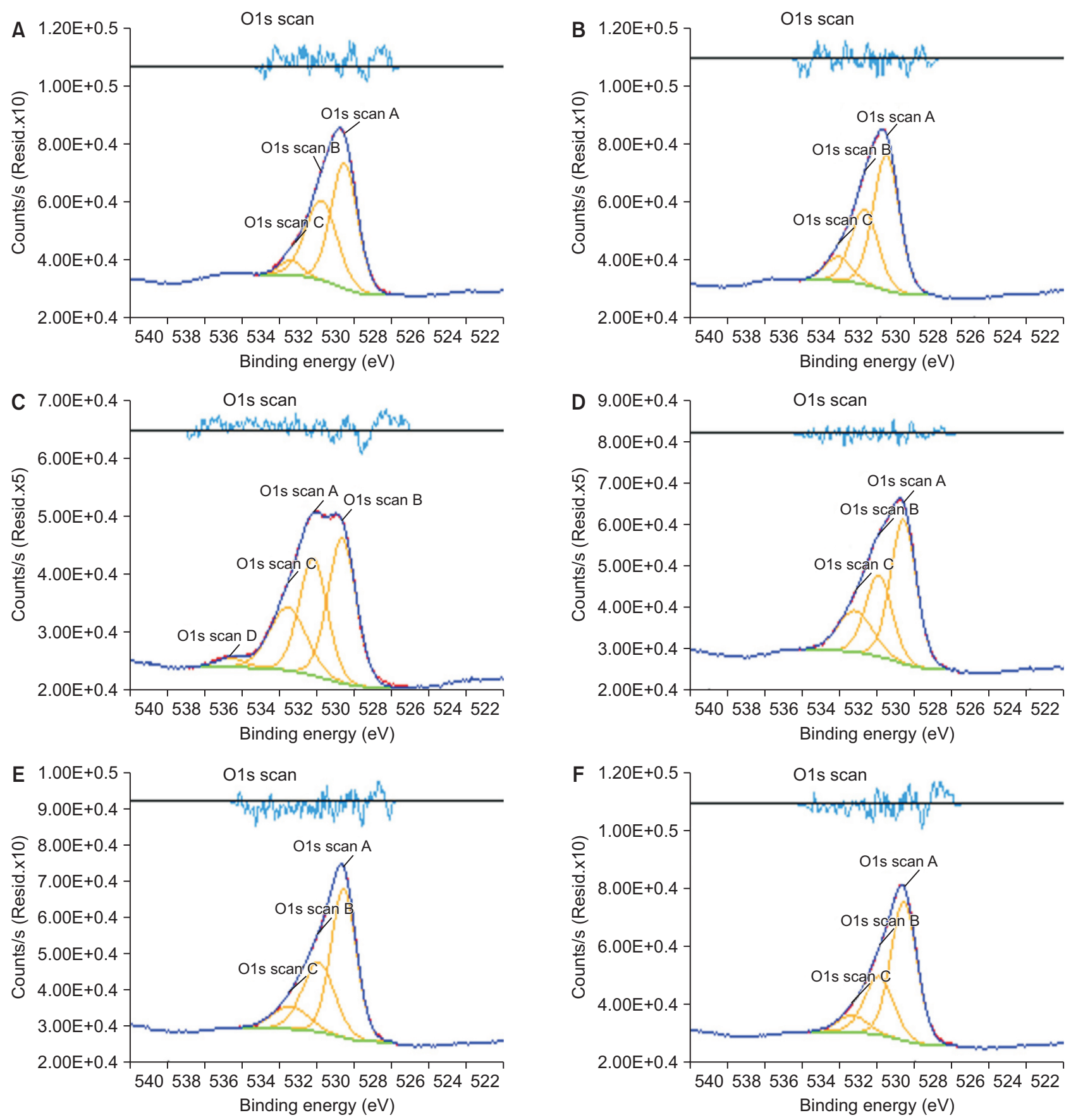

Fig. 3. X-ray photoelectron spectroscopy images of the specimens. (A) Group I: control, (B) group II: minocycline (MC) $1.5 \mathrm{mg} / \mathrm{mL} 1 \mathrm{hour}$, (C) group III: MC $1.5 \mathrm{mg} / \mathrm{mL} 24$ hour, (D) group IV: MC $15 \mathrm{mg} / \mathrm{mL} 10$ minutes, (E) group V: MC $100 \mathrm{mg} / \mathrm{mL} 5$ minutes, (F) group VI: citric acid 3 minutes.

all these considerations, the $\mathrm{MC}$ was selected for agent to treat the smooth titanium surface.

Previous studies discussed the influence of acidic treatment in the corrosion behavior of titanium surface. Wheelis et al. [19] investigated the impact of acidic treatments including tetracycline and CA on the oxide layer morphology of titanium surface. Discoloration, increase in the depth of peaks and valleys and pits on the surface of the samples were observed when acidic treatment coupled with rubbing method. Suito et al. [20] immersed specimens 
of commercially pure titanium in an acidic solution whose $\mathrm{pH}$ value was controlled using either hydrochloric or lactic acid. Eluted titanium ions were observed after 24 hours (pH 2.0 and 3.0) and after 48 hours ( $\mathrm{pH} 9.0$ ). This means that delamination of the etched oxide layer could be occurred by acidic treatment.

In this study, however, surface roughness was decreased and morphology of titanium surface was more smoothened after $\mathrm{MC}$ treatment. $\mathrm{MC}$ - and $\mathrm{CA}$-treated groups were shown to be significantly decreased in roughness.

Table 3. X-ray photoelectron spectroscopy analysis

\begin{tabular}{cccc}
\hline Group & $\mathrm{TiO}_{2}(\%)$ & $\mathrm{TiOH}(\%)$ & $\mathrm{Ti}-\mathrm{OH}(\%)$ \\
\hline Group I & 31.92 & 23.86 & 3.12 \\
Group II & 13.55 & 16.89 & 10.67 \\
Group III & 27.74 & 16.44 & 6.07 \\
Group IV & 33.11 & 18.91 & 6.08 \\
Group V & 23.21 & 13.54 & 8.97 \\
Group VI & 32.82 & 15.22 & 4.61 \\
\hline
\end{tabular}
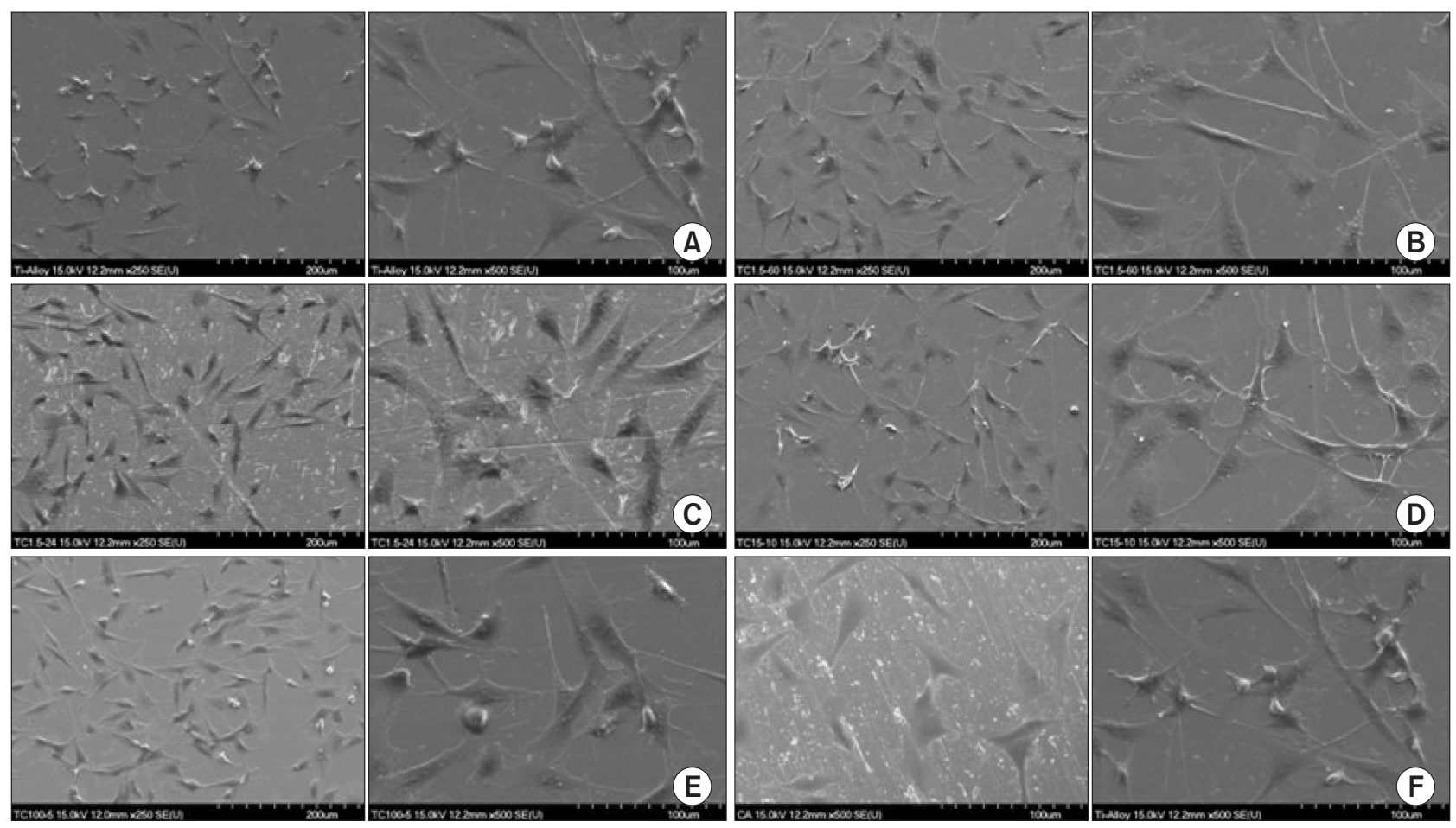

Fig. 4. The scanning electron microscopy images of cell attachment on Ti-6Al-4V alloy of each group $(1: \times 250,2: \times 500)$. (A) Group I: control, (B) group II: minocycline (MC) $1.5 \mathrm{mg} / \mathrm{mL} 1$ hour, (C) group III: MC $1.5 \mathrm{mg} / \mathrm{mL} 24$ hour, (D) group IV: MC $15 \mathrm{mg} / \mathrm{mL} 10 \mathrm{minutes}$, (E) group V: MC $100 \mathrm{mg} / \mathrm{mL} 5$ minutes, (F) group VI: citric acid 3 minutes. 
Table 5. Cell viabillity assay of samples after 3 days of culture $(n=3)$

\begin{tabular}{lc}
\hline Group & Cell viability \\
\hline Group I & $0.30 \pm 0.03$ \\
Group II & $0.94^{*} \pm 0.10$ \\
Group III & $0.78^{*} \pm 0.10$ \\
Group IV & $0.84^{*} \pm 0.10$ \\
Group V & $0.84^{*} \pm 0.11$ \\
Group VI & $0.32 \pm 0.05$ \\
\hline
\end{tabular}

Values are presented as mean \pm standard deviation.

${ }^{*}$ Significantly different from the control group, $p<0.05$.

To observe crystal structural change of titanium alloy surface, XRD analysis was performed. Results of analysis indicated that MC treatment could affect the anatase/ rutile transition of $\mathrm{TiO}_{2}$. It has been reported that rutile has better dielectric and optical properties than anatase [21]. Rutile plane has the highest atomic density and more thicken oxide layer [22]. The new peaks belonging to rutile $\mathrm{TiO}_{2}$ could be seen in group II and III. Which suggested that oxide layer thickness was increased in group II and III compared to control group.

XPS analysis was also performed to analyze the surface oxide layer and the amount of $\mathrm{OH}$ group of $\mathrm{TiO}_{2}$. Titanium dioxide surfaces have two hydroxide groups: an acidic hydroxide group (531.1 ev, TiOH) and a basic hydroxide group $(532.4 \mathrm{eV}$, Ti-OH). Ti-OH group has higher reactivity with other anions than TiOH group [23]. MC- treated groups showed more portion of $\mathrm{Ti}-\mathrm{OH}$ than that of control group. Group II and V have more basic group than the other groups. This indicates that the reactivity of $\mathrm{Ti}-\mathrm{OH}$ to other anions was increased in MC-treated groups. As a result, those groups might have higher hydrophilic surface.

Some studies reported the relationship between surface wettability and cell viability. Cell attachment or spreading and protein adsorption were influenced by surface wettability [24]. Hydrophilic surface showed improved osteoblast differentiation and alkaline phosphatase activity. Liao et al. [25] reported hydrophilic surfaces are more easily stimulate the differentiation of osteoblast in comparison with hydrophobic surfaces.

To analyze the relationship of surface modification by MC treatment and cell spreading, MC3T3-E1 cells were seeded to titanium surfaces. Although all samples show favorable cell attachment and webbing of dendritic process, more osteoblastic cells were spreading on MCtreated titanium alloy surfaces. In MC-treated groups, more cell adhesion was observed than the control group and the number of cells showing polygonal shape increased. This growth pattern could be understood by improved surface characteristics of MC treated titanium surface affect the cell attachment.

MTT assay was performed to analyze the effect of MC treatment on cell viability of osteoblastic cells on the titanium surface. At 3 days of culture, all MC-treated group showed significantly higher cell viability compared to the control group.

Similar tendency was observed on contact angle test. Significantly lower contact angle was obtained in MCtreated groups. This may explain the improved cytocompatibility of MC-treated titanium alloy surface.

Although it was well conducted, the present study has some limitations. This study evaluated the biocompatibility of the MC-treated Ti surface with osteoblast-like cells. With smooth titanium surface for material of implant abutment, microbial attachment as well as fibroblasts or epithelial cells attachment should be considered [3]. Various materials were used for fabricating implant fixtures and abutments. Zirconia has been used for implant fixtures or abutments. Therefore, future studies for surface with another material are necessary.

In conclusion, chemical agents including $\mathrm{MC}$ and $\mathrm{CA}$ were suggested to treat contaminated implant surface. In this study, $\mathrm{MC}-\mathrm{HCl}$ treatment was performed to improve biocompatibility of titanium surface. The purpose of this study was to evaluate the characteristics and the biocompatibility of the Ti- $6 \mathrm{Al}-4 \mathrm{~V}$ surface treated by the MC.

The results as follows;

Titanium surfaces treated with MC showed more smoothened surface microstructure and decreased roughness. In XRD and XPS analysis, MC treated titanium surface was shown improved osteogenic favorable surface modifications. Cell attachments and proliferation also showed significantly higher cell viability compared to control group at 3 days of culture. 
The surface roughness, crystal structure, surface hydrophilicity, cell viability of smooth titanium surface was improved by $\mathrm{MC}$ treatment. Compared with control group and $\mathrm{CA}$ treated group, smooth titanium surface immersed in $\mathrm{MC}-\mathrm{HCl}$ showed improved surface characteristics and cell biocompatibility.

\section{CONFLICT OF INTEREST}

The authors declare that they have no competing interests.

\section{ORCID}

\author{
Jung-Hyuk Lee \\ https://orcid.org/0000-0002-0413-6613 \\ Young-Gon Sun \\ https://orcid.org/0000-0002-9169-7522 \\ Eui-Ri Na \\ https://orcid.org/0000-0002-1584-8966 \\ Jong-Wook Moon \\ https://orcid.org/0000-0002-6688-0210 \\ Young-Joon Kim \\ https://orcid.org/0000-0003-1397-8166
}

\section{REFERENCES}

1. Gilbert JL. Mechanically assisted corrosion of metallic biomaterials. In: Narayan R, editor. ASM Handbook: Materials for Medical Devices. Ohio: ASM International; 2014. p. 79-89.

2. Yamazoe J, Nakagawa M, Matono Y, Takeuchi A, Ishikawa K. The development of Ti alloys for dental implant with high corrosion resistance and mechanical strength. Dent Mater J 2007;26:260-267. doi: 10.4012/dmj.26.260.

3. Kim YS, Shin SY, Moon SK, Yang SM. Surface properties correlated with the human gingival fibroblasts attachment on various materials for implant abutments: a multiple regression analysis. Acta Odontol Scand 2015;73:38-47. doi: 10.3109/00016357.2014.949845.

4. Pye AD, Lockhart DE, Dawson MP, Murray CA, Smith AJ. A review of dental implants and infection. J Hosp Infect 2009;72:104-110. doi: 10.1016/j.jhin.2009.02.010.

5. Berglundh T. Treatment of peri-implant mucositis and peri-implantitis. In: Lindhe J, Lang NP, eds. Clinical periodontology and implant dentistry. West Sussex: John
Wiley \& Sons; 2015. p. 861-869.

6. Valderrama P, Blansett JA, Gonzalez MG, Cantu MG, Wilson TG. Detoxification of implant surfaces affected by peri-implant disease: an overview of nonsurgical methods. Open Dent J 2014;8:77-84. doi: 10.2174/1874210601408010077.

7. Benet LZ, Oie S, Schwartz JB. Design and optimization of dosage regimens; pharmacokinetic data. In: Gilman AG, Goodman LS, Gilman AZ, Hardman JG, Molinoff PB, Limbird LE, editors. Goodman \& Gilman's the pharmacological basis of therapeutics. New York: McGraw-Hill; 1996. p. 1707-1792.

8. Mellonig JT, Griffiths G, Mathys E, Spitznagel J Jr. Treatment of the failing implant: case reports. Int $J$ Periodontics Restorative Dent 1995;15:384-395. doi: 10.11607/prd.00.0133.

9. Renvert S, Lessem J, Lindahl C, Svensson M. Treatment of incipient peri-implant infections using topical minocycline microspheres versus topical chlorhexidine gel as an adjunct to mechanical debridement. J Int Acad Periodontol 2004;6(4 Suppl):154-159. doi: 10.1111/j.1600051X.2006.00919.x.

10. Zhou L, Lin Y, Qiu LX, Chen B, Hu XL, Wang X. Clinical study of periocline on peri-implantitis treatment. Zhonghua Kou Qiang Yi Xue Za Zhi 2006;41:299-303.

11. Park YJ, Yeom HR, Lee SC, Lee SJ, Chung CP. Drug release kinetics, biodegradability, antimicrobial activity and cytotoxicity of $2 \%$ minocycline-loaded polysaccharide microcapsules. J Korean Soc Clin Pharmacol Ther 1995;3: 160-168.

12. Mouhyi J, Sennerby L, Pireaux JJ, Dourov N, Nammour S, Van Reck J. An XPS and SEM evaluation of six chemical and physical techniques for cleaning of contaminated titanium implants. Clin Oral Implants Res 1998;9:185-194. doi: 10.1034/j.1600-0501.1998.090306.x.

13. Elias CN, Lima JHC, Valiev R, Meyers MA. Biomedical applications of titanium and its alloys. Jom 2008;60:46-49. doi: 10.1007/s11837-008-0031-1.

14. Klinge B, Hultin M, Berglundh T. Peri-implantitis. Dent Clin North Am 2005;49:661-676. doi: 10.1016/ j.cden.2005.03.007.

15. Lindhe J, Meyle J. Peri-implant diseases: consensus report of the sixth european workshop on periodontology. J Clin Periodontol 2008;35(8 Suppl):282-285. doi: 10.1111/ j.1600-051X.2008.01283.x.

16. Schou S, Holmstrup P, Jø rgensen T, Skovgaard LT, Stoltze K, Hj ø rting-Hansen E, Wenzel A. Implant surface preparation in the surgical treatment of experimental peri-implantitis with autogenous bone graft and ePTFE membrane in cynomolgus monkeys. Clin Oral Implants Res 2003;14:412-422. doi: 10.1034/j.1600-0501.2003.00912.x.

17. Gosau M, Hahnel S, Schwarz F, Gerlach T, Reichert TE, Bürgers R. Effect of six different peri-implantitis 
disinfection methods on in vivo human oral biofilm. Clin Oral Implants Res 2010;21:866-872. doi: 10.1111/j.16000501.2009.01908.x.

18. Goodson JM. Antimicrobial strategies for treatment of periodontal diseases. Periodontol 2000 1994;5:142-168. doi: 10.1111/j.1600-0757.1994.tb00022.x.

19. Wheelis SE, Gindri IM, Valderrama P, Wilson TG Jr, Huang J, Rodrigues DC. Effects of decontamination solutions on the surface of titanium: investigation of surface morphology, composition, and roughness. Clin Oral Implants Res 2016; 27:329-340. doi: 10.1111/clr.12545.

20. Suito H, Iwawaki Y, Goto T, Tomotake Y, Ichikawa T. Oral factors affecting titanium elution and corrosion: an in vitro study using simulated body fluid. PLoS One 2013;8:e66052. doi: 10.1371/journal.pone.0066052.

21. Byun C, Jang JW, Kim IT, Hong KS, Lee BW. Anatase-torutile transition of titania thin films prepared by MOCVD. Mater Res Bull 1997;32:431-440. doi: 10.1016/S00255408(96)00203-6.
22. Jones P, Hockey JA. Infra-red studies of rutile surfaces. Part 2.- hydroxylation, hydration and structure of rutile surfaces. Trans Faraday Soc 1971;67:2679-2685. doi: 10.1039/TF9716702679.

23. Cui DZ, Park KD, Lee KK, Jung YS, Lee BA, Lee YJ, Kim OS, Chung HJ, Kim YJ. Surface characteristics and osteoblastic cell response to titanium-8tantalum-3neobium alloy. Appl Surf Sci 2012;262:107-109. doi: 10.1016/j.apsusc. 2012.02.112.

24. Wei J, Igarashi T, Okumori N, Igarashi T, Maetani T, Liu B, Yoshinari M. Influence of surface wettability on competitive protein adsorption and initial attachment of osteoblasts. Biomed Mater 2009;4:045002. doi: 10.10 88/1748-6041/4/4/045002.

25. Liao H, Andersson AS, Sutherland D, Petronis S, Kasemo B, Thomsen P. Response of rat osteoblast-like cells to microstructured model surfaces in vitro. Biomaterials 2003; 24:649-654. doi: 10.1016/S0142-9612(02)00379-4. 